Article

\title{
Explaining Leaf Nitrogen Distribution in a Semi-Arid Environment Predicted on Sentinel-2 Imagery Using a Field Spectroscopy Derived Model
}

\author{
Abel Ramoelo ${ }^{1,2, *(D)}$ and Moses Azong Cho ${ }^{1,3}$ (D) \\ 1 Earth Observation Research Group, Natural Resources and the Environment Unit, \\ Council for Scientific and Industrial Research (CSIR), Pretoria 0001, South Africa; mcho@csir.co.za \\ 2 Risk and Vulnerability Assessment Centre, University of Limpopo, Sovenga 0727, South Africa \\ 3 Department of Plant and Plant Science, University of Pretoria, Pretoria 0001, South Africa \\ * Correspondence: aramoelo@csir.co.za or abel.ramoelo@gmail.com; Tel.: +27-012-841-3968
}

Received: 7 December 2017; Accepted: 5 February 2018; Published: 9 February 2018

\begin{abstract}
Leaf nitrogen concentration (leaf $\mathrm{N}, \%$ ) is an essential component for understanding biogeochemical cycling. Leaf $\mathrm{N}$ is a good indicator of grass or forage quality, which is important for understanding the movements and feeding patterns of herbivores. Leaf $\mathrm{N}$ can be used as input for rangeland carrying capacity and stocking rate models. The estimation of leaf $\mathrm{N}$ has been successful using hyperspectral and commercial high spatial resolution satellite data such as WorldView-2 and RapidEye. Empirical methods have been used successfully to estimate leaf N, on the basis that it correlates with leaf chlorophyll. As such, leaf $\mathrm{N}$ was estimated using red edge based indices. The new Sentinel-2 sensor has two red edge bands, is freely available, and could further improve the estimation of leaf $\mathrm{N}$ at a regional scale. The objective of this study is to develop red edge based Sentinel-2 models derived from an analytical spectral device (ASD) spectrometer to map and monitor leaf N using Sentinel-2 images. Field work for leaf N and ASD data were collected in 2014 (December) in and around Kruger National Park, South Africa. ASD data were resampled to the Sentinel-2 spectral configuration using the spectral response function. The Sentinel-2 data for various dates were acquired from the European Space Agency (ESA) portal. The Sentinel-2 atmospheric correction (Sen2Cor) process was implemented. Simple empirical regression was used to estimate leaf N. High leaf $\mathrm{N}$ prediction accuracy was achieved at the ASD level and the best model was inverted on Sentinel-2 images to explain leaf $\mathrm{N}$ distribution at a regional scale over time. The spatial distribution of leaf $\mathrm{N}$ is influenced by the underlying geological substrate, fire frequency and other environmental variables. This study is a demonstration of how ASD data can be used to calibrate Sentinel-2 for leaf $\mathrm{N}$ estimation and mapping.
\end{abstract}

Keywords: leaf nitrogen; grass quality; field spectrometer; Sentinel-2; mapping; red edge band

\section{Introduction}

Rangelands cover about $51 \%$ of the Earth's land surface [1,2] and provide food production for millions of the world population. Most of the millions of people relying on rangelands for their daily sustenance, are rural and sometimes poor communities. The human population in 2050 is projected to be more than 9 billion and most of the increase is estimated to be in developing countries, with more than half in Africa [3]. Rapid increases in population will cause changes in land cover and land use, which impact rangelands and food security through land degradation [4,5]. Land degradation is regarded as a threat to the productivity of rangelands [5]. Degradation or loss of rangeland potential to provide grazing resources is also exacerbated by continued global climatic change [6]. Climate change induces erratic rainfall and increases temperatures. As a result, disasters such as drought become 
prevalent in Africa, affecting a high proportion of livestock production by reducing the availability and quality of grazing forage resources.

Drought as a consequence of climate change is devastating rangelands and livestock systems in Africa. The occurrence of drought limits the carrying capacity and stocking rates of the rangelands. Livestock mortality, which is common during this period has many implications for the livelihood of the local community. The development of techniques to examine the state, extent and quality of rangeland is critical. In this context, leaf nitrogen (leaf $\mathrm{N}$ ) could be useful to assess the quality of rangeland, and thus inform decision makers on planning and management.

Leaf $\mathrm{N}$ concentration is an essential component for understanding biogeochemical cycling and a good indicator of vegetation vitality [7] and grass or forage quality (i.e., protein) which is important for understanding the movements and feeding patterns of herbivores [8,9]. Leaf $\mathrm{N}$ is a key component for determining vegetation conditions, and is useful for determining livestock carrying capacity and stocking rates. It is critical to have the latter indicators on order to circumvent the problems of over-grazing, soil erosion and land degradation which impact negatively on rangeland conditions and hence livestock production.

The conventional approach to assessing the spatial and temporal distribution of leaf $\mathrm{N}$ in rangelands is reliant on extensive field data collection which is expensive, labour intensive and time consuming, especially for wider geographic areas. Satellite remote sensing provides an alternative approach for mapping leaf $\mathrm{N}$ for wide geographic areas and over time. The estimation of leaf $\mathrm{N}$ in grass has been successful using hyperspectral data with both field spectrometer and airborne data [10-13]. The latter was possible because of the development of the second generation of vegetation indices such as the red edge position (REP) $[14,15]$ and narrow band indices which are sensitive to subtle changes in leaf chlorophyll content in contrast to the traditional Normalized Difference Vegetation Index (NDVI) which saturates at high green vegetation canopy cover [11,16-19]. The new generation of satellite constellations has strategically incorporated the red edge band to improve vegetation and crop condition monitoring. These include commercial satellites such as WorldView-2/3 and RapidEye. However, the data from these sensors comes at an almost prohibitive cost, especially for the developing world. On the other hand, Sentinel-2, a multispectral satellite developed and launched by the European Space Agency (ESA) which features 13 spectral bands in the visible to shortwave infrared and including two red edge bands $(705 \mathrm{~nm}$ and $740 \mathrm{~nm}$ ) provides freely available images. Like Landsat, Sentinel-2 data are freely available and could be useful to improve the assessment of crop and rangeland biochemical and biophysical variables.

To date, empirical methods for estimating leaf $\mathrm{N}$ require basic and complex statistical analysis-from simple to machine learning regression [16-18,20,21]. The simple empirical approach assumes that leaf $\mathrm{N}$ is significantly related to specific chlorophyll-based vegetation indices [22-25]. The assumption is that leaf nitrogen is related to chlorophyll [26] and the red edge based vegetation indices capture subtle changes in vegetation vigour. On the other hand, some methods assume that the estimation of leaf $\mathrm{N}$ is not dependent exclusively on one vegetation index or reflectance at a specific band, but also a combination of variables-integrated modelling using reflectance, indices and also environmental variables $[10,13]$. The latter approach was achieved by using stepwise multiple linear regressions (SMLR), partial least square regression (PLSR), machine learning techniques including artificial neural network (ANN) $[17,18]$. The machine learning techniques are non-parametric in nature and are known to perform better than the parametric ones for grass $\mathrm{N}$ estimation $[12,17,18]$, and could be critical for monitoring grass nutrients using Sentinel-2.

Deriving leaf $\mathrm{N}$ concentration for monitoring purposes using satellite remote sensing is always hindered by the availability of field data collected simultaneously with the image acquisition, which is a common practice for leaf $\mathrm{N}$ model development. In this study, we intend to explore the use of the spectrometer data with corresponding field $\mathrm{N}$ to calibrate and map grass $\mathrm{N}$ using Sentinel- 2 data. The spectrometer data will be used to simulate Sentinel-2 spectral bands by a resampling technique and the leaf $\mathrm{N}$ model will be developed independent of the Sentinel-2 image. Ramoelo et al. [18] 
demonstrated that the simulated Sentinel-2 image coupled with the machine learning techniques improves the estimation of leaf nitrogen concentrations. The red edge and the SWIR bands were found to be important in the estimation of leaf N. In this study, only the visible to near infrared data will be investigated to assess the usefulness of the red edge band in Sentinel-2 data for mapping and monitoring leaf $\mathrm{N}$. The study by Cho et al. [27] demonstrated a consistent performance of red edge based indices on the estimation of herbaceous biomass from HyMap images acquired from different dates, compared to conventional vegetation indices such as NDVI. This study will further test the influence of environmental factors, such as the underlying geological types, climatic, topographic features and fire frequency on leaf $\mathrm{N}$, which are some of the major determinants of savanna ecosystems [28-31].

\section{Materials and Methods}

\subsection{Study Area}

The study area is located in the north-eastern part of South Africa in the Lowveld savanna (Figure 1). The Lowveld landscape is a low lying area extending from the foot slopes of the Drakensberg Great Escarpment to the west and the Mozambique coastal plain to the east (Venter et al., 2003). The topography is gently undulating with flat patches in localized areas, and with an average height of $450 \mathrm{~m}$ a.s.l. The study area covers a land use transect ranging from protected areas such as the Sabi Sands Private Game Reserve and the state-owned Kruger National Park (KNP) to communal lands in the Bushbuckridge region. The western part of the transect (communal areas) receives higher mean annual rainfalls $(800 \mathrm{~mm} /$ year) as compared to the eastern side of the transect ( $580 \mathrm{~mm} /$ year). The annual mean temperature is about $22^{\circ} \mathrm{C}$. The dominant geology includes granite and gneiss with local intrusions of gabbro as well as basalt [28].

Gradients of soil moisture and nutrients are important in this area. The soil fertility of gabbro areas is higher than the granitic ones (Venter et al., 2003). The main vegetation communities include the "granitic lowveld" and the "gabbro grassy bushveld" [32]. In the gabbro patches, grass species such as Setaria sphacelata dominate the crest while species such as Urochloa mosambicensis dominate the valleys. Gabbro patches are dominated by grass species with high productive potential (e.g., Urochloa mosambicensis) compared to granite-derived soils (e.g., Eragrostis rigidior and Pogonarthria squarrosa. Also, the gabbro sites are dominated by fine-leaved tree species such as Acacia spp. while the granite sites are dominated by broad-leaved tree species such as Combretum spp. and Terminalia spp.) [16-18]. Another geology type is basalt, which has similar characteristics to gabbro, see Ramoelo et al. [16].

\subsection{Field Data Collection}

The field data collection was done in December 2014 along the land use gradient from Bushbuckridge communal areas, Sabie Sands and Kruger National Park, covering granite, gabbro and basalt geological types (Figure 1). The site selection process captured the nutrient contrast from low to high between granitic, gabbro and basalt derived soils, respectively, and along the rainfall gradient (east-west). To further ensure grass biomass variability, transects were laid out to sample both valley and crest land units. Grass biomass in the savanna ecosystems is also influenced by topography with valley areas generally having higher grass biomass than crest areas. Purposive and road sampling was done for placement of sampling plots since we could not penetrate deep into the savanna because of management restrictions. The $300 \mathrm{~m}$ buffers were created on both sides of the selected roads. Within the buffer polygons, random sample points were generated using the ArcGIS add-on, called Hawth tools. All the points falling on the road and open areas next to the road were rejected because of the unavailability of grass. A total of 30 plots were surveyed. Each randomly selected sample point was treated as a plot with a size of $20 \mathrm{~m} \times 20 \mathrm{~m}$. To capture the variability in each plot, two subplots of size $50 \mathrm{~cm} \times 50 \mathrm{~cm}$ were used to collect data about the dominant species and grass samples. The grass 
samples were cut for chemical analysis to retrieve leaf $\mathrm{N}$ concentrations. Grass samples were dried at $80^{\circ} \mathrm{C}$ for $24 \mathrm{~h}$ and were chemically analysed for leaf N (\%) at the Bemlab, Strand, Western Cape South Africa [17].

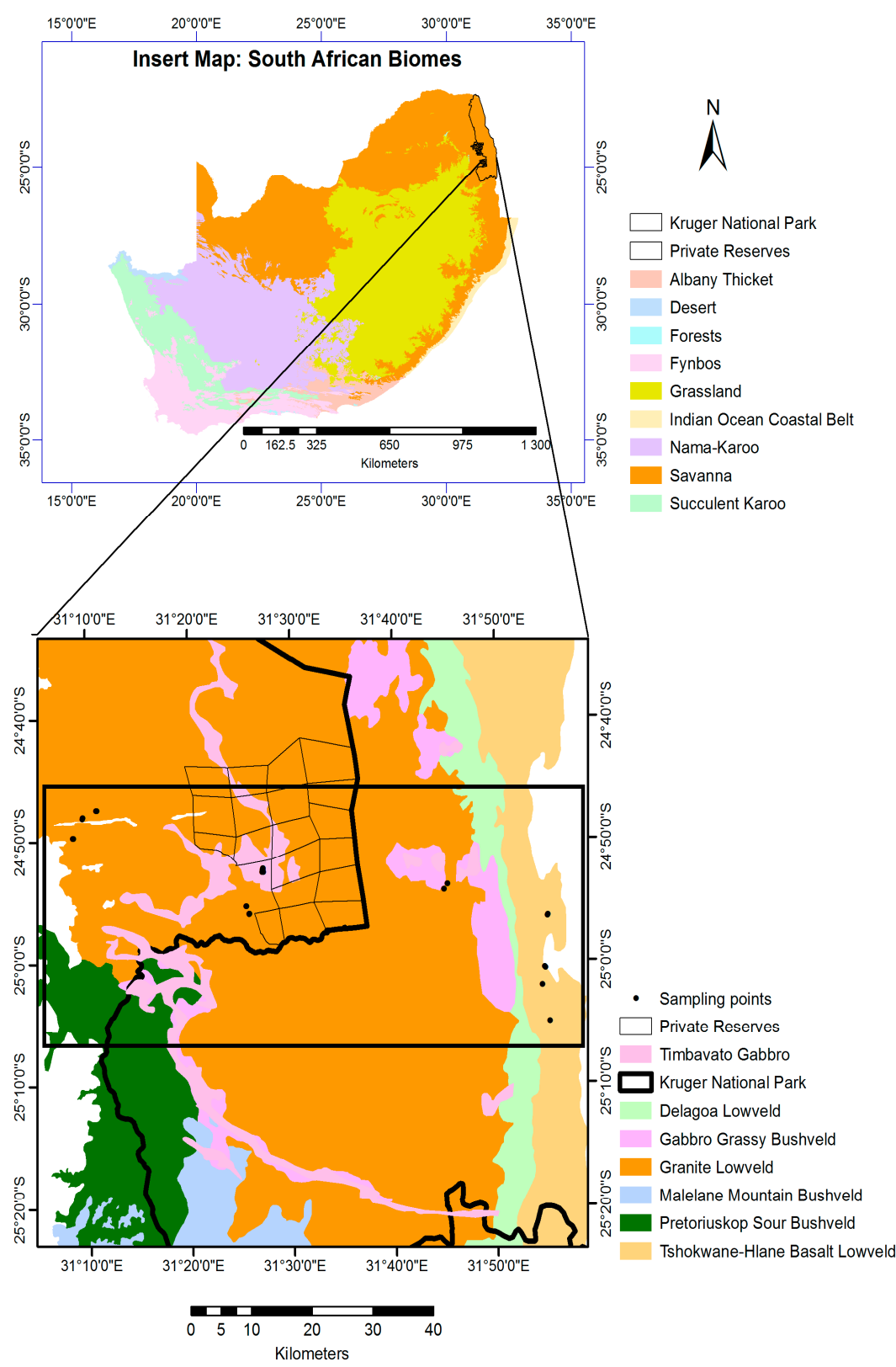

Figure 1. Study area locality map. Top: vegetation map, [32].

\subsection{Spectral Measurements}

The reflectance spectra were measured in the field using an Analytical Spectral Device (ASD) spectroradiometer, Fieldspec $3^{\circledR}$ (Figure 2). The ASD spectral domain ranges from 350 to $2500 \mathrm{~nm}$, with $1 \mathrm{~nm}$ band width. Within each plot, spectral measurements were made for each of the two subplots [18]. In each subplot, five spectral measurements were taken and later averaged to account for illumination and grass canopy structural differences as well as bidirectional effects [18]. The measurements were taken between $10 \mathrm{~h} 30$ and $15 \mathrm{~h} 00$ on clear sunny days with minimal cloud cover to maximize illumination. The $25^{\circ}$ field-of-view fibre optic was used and was placed at $1 \mathrm{~m}$ above 
the ground and at nadir to cover the entire subplot. Before each spectral measurement, a Spectralon reference panel was used to calibrate the sensor and convert spectral radiance to reflectance.

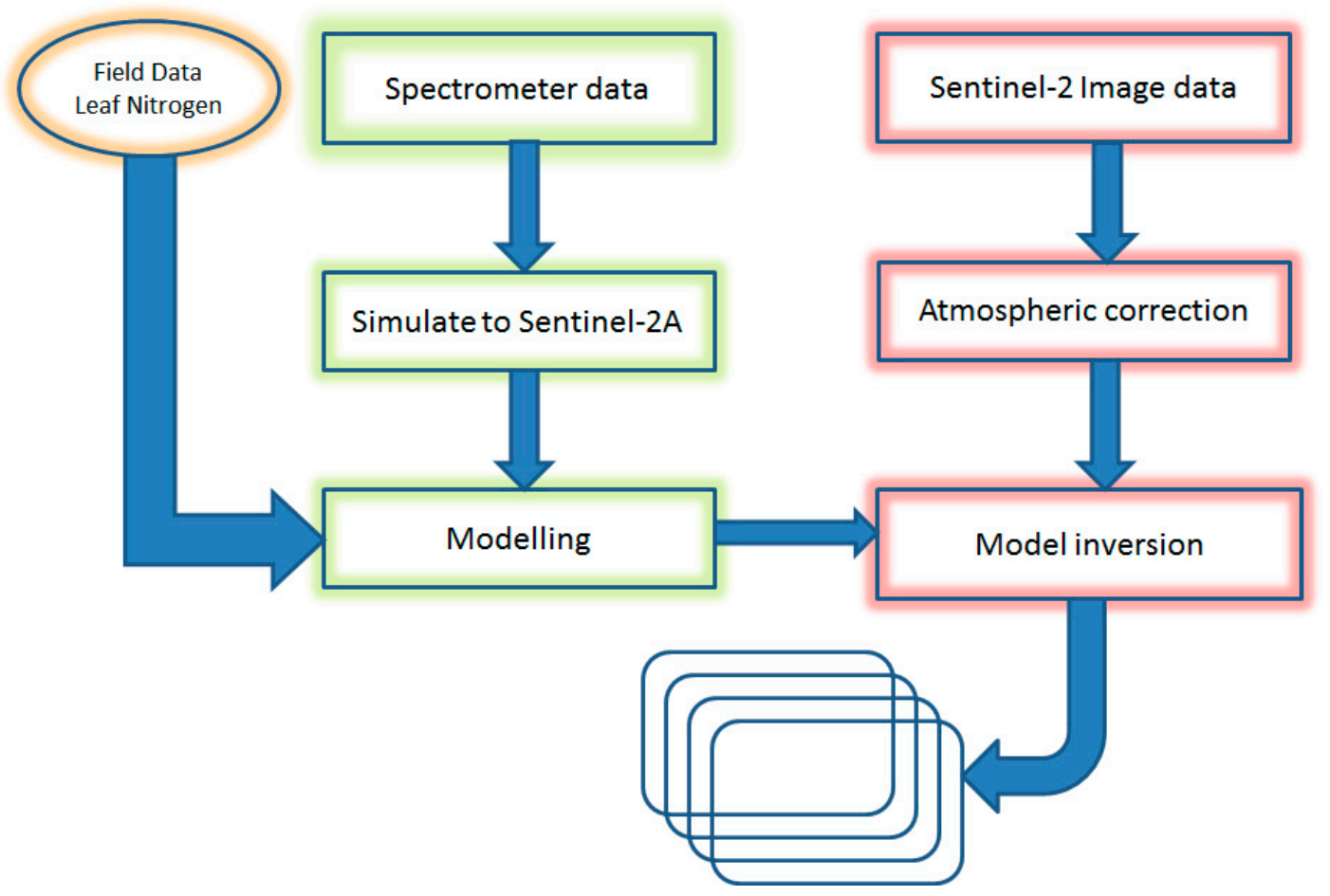

Figure 2. Flow chart conceptualizing the process or methods followed in this study.

\subsection{Image Acquisition and Preprocessing}

About nine Sentinel-2A images were freely acquired from the European Space Agency data hub dated from 26 December 2015 to 11 October 2016 (Table 1). The image was comprised of 13 bands ranging from visible to shortwave infrared [18]. Of the available bands or wavelength, there are two red edge bands centred at 705 and $740 \mathrm{~nm}$. The atmospheric correction was implemented using the Sentinel-2 atmospheric correction tool (Sen2Cor) performed on Sandbox handled by Terradue and CSIR's Meraka Institute. Sen2cor is a prototype processor or tool that undertakes atmospheric, terrain and cirrus correction. It is implemented with a large database of look-up tables (LUT) compiled using an atmospheric radiative transfer model based on libRadtran1. The LUT include a wide variety of atmospheric conditions, solar geometries and ground elevations computed with high spectral resolution of $0.6 \mathrm{~nm}$. In order to get the sensor specific functions for Sentine-2, the database have been spectrally resampled using the Sentinel-2 spectral response function (http:/ / step.esa.int/main/thirdparty-plugins-2/sen2cor/).

Table 1. List of Sentinel-2 images used in the study.

\begin{tabular}{ccc}
\hline Image No. & \multicolumn{1}{c}{ Reference } & Dates \\
\hline 1 & S2A_T36JUT_R092_20151226 & 16 December 2015 \\
2 & S2A_T36JUT_R092_20160504 & 4 April 2016 \\
3 & S2A_T36JUT_R092_20160524 & 23 April 2016 \\
4 & S2A_T36JUT_R092_20160723 & 23 July 2016 \\
5 & S2A_T36JUT_R092_20160812 & 12 August 2016 \\
6 & S2A_T36JUT_R092_20160822 & 22 August 2016 \\
7 & S2A_T36JUT_R092_20160901 & 1 September 2016 \\
8 & S2A_T36JUT_R092_20160921 & 21 September 2016 \\
9 & S2A_T36JUT_R092_20161011 & 11 October 2016 \\
\hline
\end{tabular}




\subsection{Data Analysis}

\subsubsection{Development of Leaf N Predictive Model}

Field measured reflectance spectral data were resampled to Sentinel-2 wavelength configuration using the respective spectral response function (Figure 2). Several indices were computed including the red edge based indices. The normalized difference vegetation indices $(\mathrm{NDVI})=(\mathrm{NIR}-\mathrm{R}) /(\mathrm{NIR}+\mathrm{R})$ and the simple ratio (SR) $=$ NIR/R [33] were computed, where NIR was near-infrared and $R$ was the red region of the spectrum. The red edge based indices for both NDVI and SR were computed as follows (NIR vs. R); RE1 ( $R_{740}$ vs. $\left.R_{665} \mathrm{~nm}\right), \operatorname{RE} 2\left(R_{705}\right.$ vs. $\left.R_{665} \mathrm{~nm}\right), \operatorname{RE} 3\left(R_{783}\right.$ vs. $\left.R_{705 \mathrm{~nm}}\right)$ [34,35], RE4 $\left(R_{783}\right.$ vs. $\left.R_{740} \mathrm{~nm}\right), \operatorname{RE5}\left(R_{842}\right.$ vs. $\left.R_{705} \mathrm{~nm}\right), \operatorname{RE6}\left(R_{842}\right.$ vs. $\left.R_{740} \mathrm{~nm}\right)$ and RE7 $\left(R_{740}\right.$ vs. $\left.R_{705} \mathrm{~nm}\right)$ [35-37]. Chlorophyll-red edge based index $\left(\mathrm{CI}_{\text {red-edge }}\right)=\left(R_{783} / R_{705}\right)-1[35,38,39]$ and the $\mathrm{CI}_{\text {green }}=\left(R_{783} / R_{560}\right)-1[35,38,39]$. The MERIS Terrestrial Chlorophyll Index (MTCI) was also computed based on the bands centred at $705 \mathrm{~nm}, 740 \mathrm{~nm}$ and $665 \mathrm{~nm}\left(R_{740}-R_{705} / R_{705}-R_{665}\right)$ [40]. The red edge position (REP) based on a linear four-point interpolation method, was computed and Sentinel-2 bands centred at 663, 705, 740 and $783 \mathrm{~nm}$ were used; see Guyot and Baret [41]. Simple linear regression with bootstrapping was used to validate leaf $\mathrm{N}$ models based on various remote sensing variables (indices and bands), and was implemented in R programming language ("Boot function package"). Bootstrapping was used because of the small sample size and it is an unbiased means of evaluating the performance of various estimation models [42-44]. Bootstrapping technique subsets $\sim 70 \%$ of data for calibration of the regression model and validates with the remainder, iteratively, and 1000 interactions were used in this study. Ramoelo et al. [16-18] and Mutanga and Skidmore [19] are examples of successful validation of regression models using this technique (bootstrapping). Statistical accuracy and precision metrics such as the coefficient of determination $\left(R^{2}\right)$, root mean square error (RMSE) and relative RMSE (\%) were used. The relative RMSE was computed by dividing the RMSE by the observed mean and multiplying by 100 .

Additional independent validation was undertaken using the leaf $\mathrm{N}$ and RapidEye data collected in 2010, from Ramoelo et al. [16]. Firstly, the red edge-based vegetation index was derived using RapidEye data. Leaf $\mathrm{N}$ will be predicted using Sentinel-2 derived model applied to the corresponding and selected RapidEye based vegetation index. Finally, the statistical accuracy will be computed based on the predicted and measured leaf $\mathrm{N}$ values. The assumption here is that Sentinel-2 red edge based model should be able to estimate leaf $\mathrm{N}$ using RapidEye's red edge based indices-to confirm the transferability and stability of the red edge based models. The red edge bands for Sentinel-2 and RapidEye are comparable, $705 \mathrm{~nm}$ and $710 \mathrm{~nm}$, respectively. The first red edge band $(705 \mathrm{~nm})$ of Sentinel-2 has been found to be more important in estimating leaf $\mathrm{N}$ using machine learning techniques [18] and it is expected to perform better in estimating leaf $\mathrm{N}$ when transformed to indices.

\subsubsection{Explaining Leaf N Distribution}

For explanatory analysis, over 200 randomly points were generated to the extent of the Sentinel-2 image, and used to extract predicted leaf $\mathrm{N}$ values and fire frequency (number of times a grid of $90 \mathrm{~m}$ $\times 90 \mathrm{~m}$ is burnt) from 2005 to 2015, acquired from South African National Parks (SANPARKS, Skukuza, South Africa), long-term mean annual precipitation $(\mathrm{mm})$ (worldclim.com), topographic features (e.g., digital elevation model (m), slope (degree) and aspect (degree) from a $30 \mathrm{~m}$ Shuttle Radar and Topography Mission (SRTM30) (https://dds.cr.usgs.gov/srtm/version2_1/SRTM30/), and geology data acquired from the Council for Geosciences (South Africa) and produced in 2008. Correlation analysis was done to determine the relationship between leaf $\mathrm{N}$ concentrations and various continuous variables such as precipitation and topographic features. Analysis of variance (ANOVA) was used to test for significance differences between leaf $\mathrm{N}(\%)$ and categorical variables such as geology and fire frequency. 


\section{Results and Discussion}

\subsection{Descriptive Statistics}

The variation of leaf $\mathrm{N}$ across the study areas was moderate with a co-efficient of variation about 36\% (Table 2). Lower values are associated with the granite, while the higher end of the leaf $\mathrm{N}$ values represents the gabbro and basalt geological sampling sites. In the heterogeneous systems of the savanna, multiple factors such as fire, geology, soils and climate influence the distribution of leaf $\mathrm{N}$ [28]. There is no correlation between leaf $\mathrm{N}$ and herbaceous biomass $\left(\mathrm{g} / \mathrm{m}^{2}\right)\left(R^{2}=0.0064, p=0.669\right)$. This shows that the estimation of leaf $\mathrm{N}$ is minimally influenced by the interaction effects of biomass and leaf $\mathrm{N}[12,16]$.

Table 2. Descriptive statistics for leaf N (\%) across the study area.

\begin{tabular}{ccccc}
\hline Min & Max & Mean & CV (\%) & N \\
\hline 0.54 & 2.05 & 0.88 & 36.35 & 30 \\
\hline \multicolumn{6}{c}{ CV = Coefficient of Variation. }
\end{tabular}

\subsection{Leaf N Predictive Models}

Sentinel-2's red edge based simple ratio index (SR_RE3—based on 783 and 705 nm), MTCI, CIred edge explained over $75 \%$ of the leaf $\mathrm{N}$ variation, with $19 \%$ error, respectively (Table 3). Red edge position based on the Linear Interpolation method yielded about $70 \%$ of the leaf $\mathrm{N}$ variation. Even though most of the bands yielded a significant relationship with leaf $\mathrm{N}$, their coefficient of determination $\left(R^{2}\right)$ and relative root mean square error (\%) indicated poor performance as compared to the red edge based vegetation indices-SR and the NDVI. In addition, red edge based indices such as CI and MTCI performed equally well. From spectroscopy studies, it was demonstrated that the red edge based indices are significantly related to chlorophyll and $\mathrm{N}$ concentrations $[14,21,26]$. Often, leaf $\mathrm{N}$ is indirectly estimated using red edge information because it is related to chlorophyll [14,26]. Red edge indices making use of $705 \mathrm{~nm}$ and any near infrared band yielded the highest accuracy for estimating leaf $\mathrm{N}$ concentrations (Figure 3, Table 3). The latter band (705 $\mathrm{nm}$ ) is placed at the onset of the high reflectivity portion of the vegetation response, and is crucial for plant health estimation (e.g., leaf $\mathrm{N}$ or chlorophyll) while the second red edge band $(740 \mathrm{~nm})$ is influenced by the concerted effects of plant health (e.g., leaf $\mathrm{N}$ or chlorophyll) [14] and the vegetation structure (e.g., leaf area index and biomass) [14,18]. Results for this study concurs with other studies that evaluated the applicability of the multispectral red edge bands for mapping vegetation quality or health in the grasslands or savanna [16-18,45] subtropical forests [46] and Mediterranean forests (Loozen et al., 2017) [47]. In addition, the notable performance of the MTCI on the estimation of N content or concentrations has been further reported by Cho et al. [46]; Ullah et al. [45] and Loozen et al. [47].

The leaf $\mathrm{N}$ model based on SR-RE3 was evaluated using independent leaf $\mathrm{N}$ and RapidEye data collected from the same area during peak productivity (March 2010) [16]. The predicted leaf $N$ values were significantly correlated to the measured data collected in 2010, with acceptable accuracy $(r=0.48$ $\left(R^{2}=0.23\right)$, RMSE $\left.=0.36 \%\right)$. Figure 4 , shows the scatterplot indicating a relationship between observed and predicted leaf $\mathrm{N}$ values. The performance of the SR_SR3 model (this study) is comparable with the significant model achieved using RapidEye data $\left(R^{2}=0.23\right.$, RMSE $\left.=0.15 \% \mathrm{~N}\right)$ [16]. This further highlights the potential of the red edge band in developing transferable models.

Sentinel-2 data sets are set to improve the estimation of leaf $\mathrm{N}$ at various scales, including the global scale, in a cost-effective manner. The strategic placement of the two red edge bands provide an opportunity to estimate and map leaf $\mathrm{N}$ during peak productivity. Ramoelo et al. [18], indicated that Sentinel-2's short-wave infrared bands are important in the estimation of leaf N (1610 and $2190 \mathrm{~nm})$, which further provides an opportunity to estimate leaf $\mathrm{N}$ during the dry season. In this study, we used only the visible-near infrared (VNIR) spectral regions to further explore the utility of the two red 
edge bands. The results achieved here are comparable with that of Ramoelo et al. [16] where red edge based indices-from RapidEye images were used to regionally map leaf N, (see also Figure 4. Zengeya et al. [48] and Ramoelo et al. [18]) and indicated that WorldView-2, has the potential to estimate leaf $\mathrm{N}$ with comparable accuracy. The main disadvantage of using RapidEye and WorldView data is the cost, and it might not be affordable for most developing countries. The main shortcoming of the latter models is that they are site, data, and season specific and cannot be easily transferred. Ramoelo et al. [18] demonstrated that machine learning techniques, such as random forest improved the estimation of leaf $\mathrm{N}$ by $49 \%$, and are robust, if well parameterized. Ramoelo et al. [18] and this study demonstrated that Sentinel-2 can be used to accurately estimate leaf $\mathrm{N}$ concentrations.

Table 3. Performance of bands and various vegetation indices on the estimation of leaf $\mathrm{N}$ using simulated Sentinel-2 spectral configuration from spectrometer data.

\begin{tabular}{|c|c|c|c|c|}
\hline Variables & $R^{2}$ & RMSE (\%N) & RRMSE (\%) & $p<0.05$ \\
\hline $443 \mathrm{~nm}$ & 0.11 & 0.31 & 35.23 & No \\
\hline $490 \mathrm{~nm}$ & 0.14 & 0.30 & 34.09 & Yes \\
\hline $560 \mathrm{~nm}$ & 0.01 & 0.32 & 36.36 & No \\
\hline $665 \mathrm{~nm}$ & 0.27 & 0.28 & 31.82 & Yes \\
\hline $705 \mathrm{~nm}$ & 0.15 & 0.30 & 34.09 & Yes \\
\hline $740 \mathrm{~nm}$ & 0.23 & 0.29 & 32.95 & Yes \\
\hline $783 \mathrm{~nm}$ & 0.30 & 0.27 & 30.68 & Yes \\
\hline $842 \mathrm{~nm}$ & 0.27 & 0.28 & 31.82 & Yes \\
\hline REP & 0.70 & 0.18 & 20.45 & Yes \\
\hline NDVI & 0.59 & 0.21 & 23.86 & Yes \\
\hline NDVI1 & 0.60 & 0.21 & 23.86 & Yes \\
\hline NDVI_RE1 & 0.59 & 0.21 & 23.86 & Yes \\
\hline NDVI_RE2 & 0.51 & 0.23 & 26.14 & Yes \\
\hline NDVI_RE3 & 0.69 & 0.18 & 20.45 & Yes \\
\hline NDVI_RE4 & 0.73 & 0.17 & 19.32 & Yes \\
\hline NDVI_RE5 & 0.69 & 0.18 & 20.45 & Yes \\
\hline NDVI_RE6 & 0.22 & 0.29 & 32.95 & Yes \\
\hline NDVI_RE7 & 0.68 & 0.19 & 22.00 & Yes \\
\hline SR & 0.70 & 0.18 & 20.45 & Yes \\
\hline SR1 & 0.70 & 0.18 & 20.45 & Yes \\
\hline SR_RE1 & 0.68 & 0.18 & 20.45 & Yes \\
\hline SR_RE2 & 0.56 & 0.22 & 25.00 & Yes \\
\hline SR_RE3 & 0.75 & 0.17 & 19.32 & Yes \\
\hline SR_RE4 & 0.74 & 0.17 & 19.32 & Yes \\
\hline SR_RE5 & 0.74 & 0.17 & 19.32 & Yes \\
\hline SR_RE6 & 0.22 & 0.29 & 32.95 & Yes \\
\hline SR_RE7 & 0.72 & 0.17 & 19.32 & Yes \\
\hline $\mathrm{CI}_{\text {red edge }}$ & 0.75 & 0.17 & 19.32 & Yes \\
\hline $\mathrm{CI}_{\text {green }}$ & 0.69 & 0.18 & 20.45 & Yes \\
\hline MTCI & 0.75 & 0.17 & 19.32 & Yes \\
\hline
\end{tabular}

REP = Red Edge Position; SR = Simple Ratio; NDVI = Normalized Difference Vegetation Index; RE $=$ Red Edge; MTCI-MERIS Terrestrial Chlorophyll Index; CI = Chlorophyll index. 


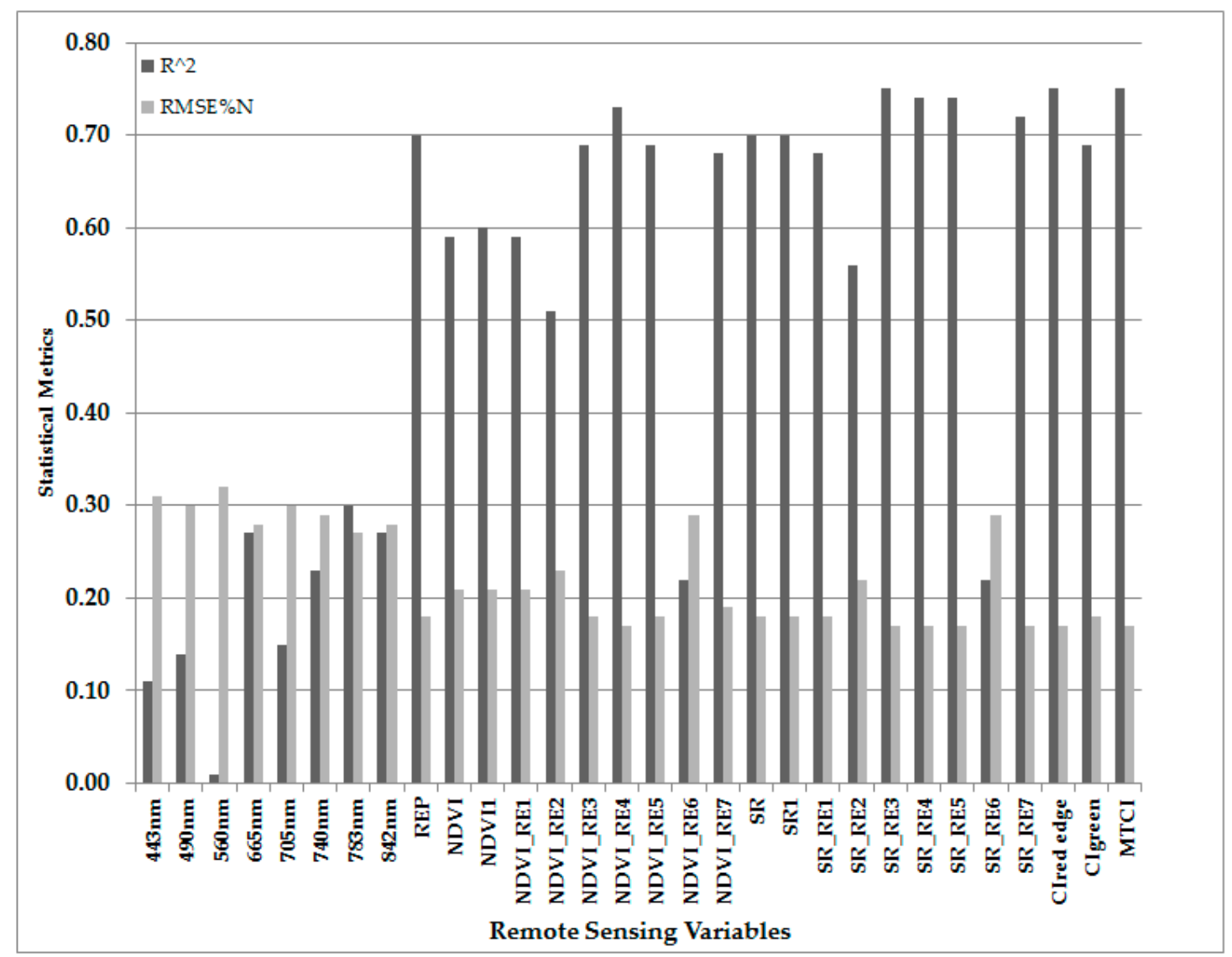

Figure 3. Comparison of the leaf $\mathrm{N}$ estimation performance using bands and various indices, including red edge based indices derived from Sentinel-2 data sets.

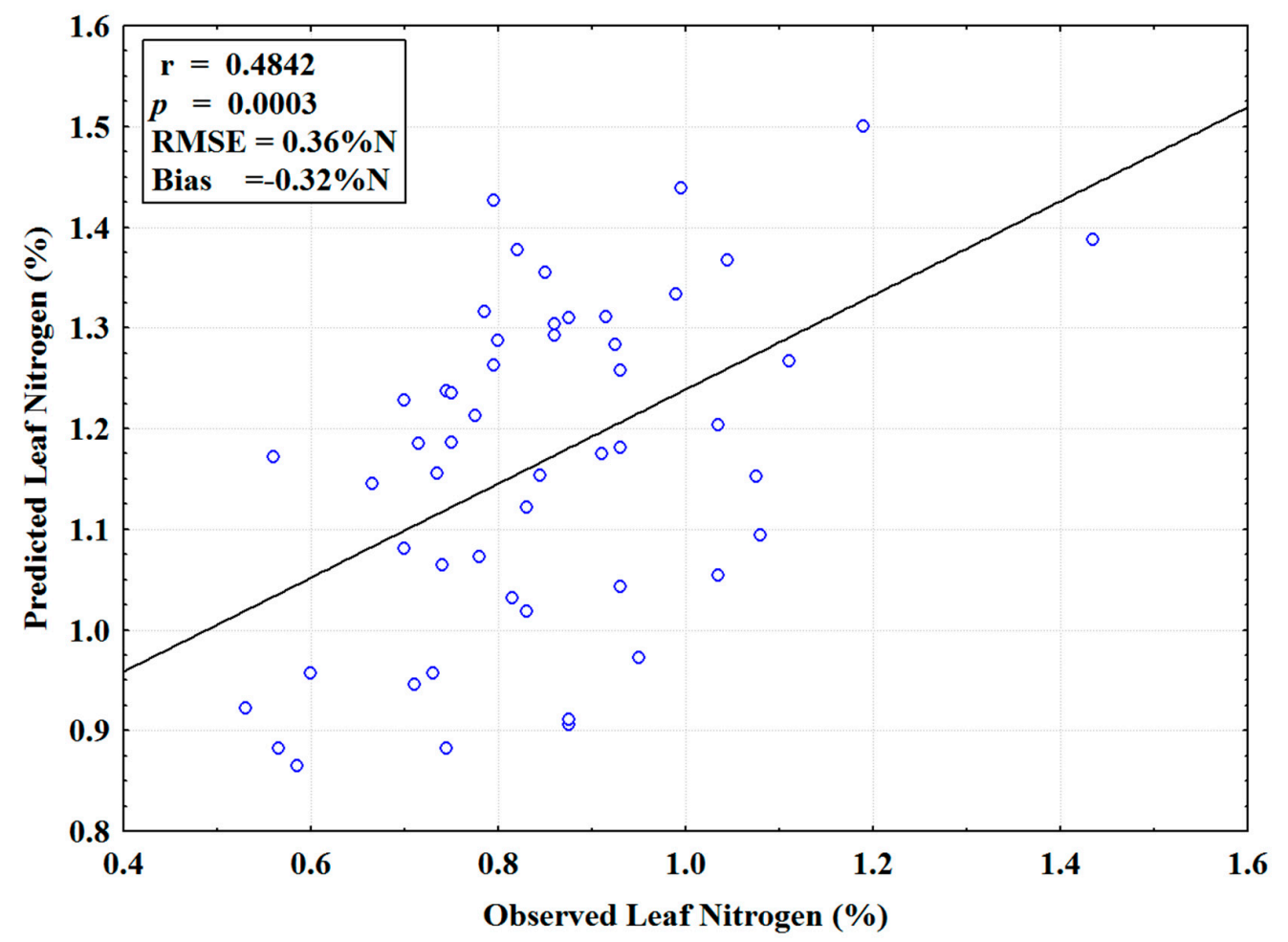

Figure 4. Independent validation of the selected model (SR_RE3) for mapping leaf $\mathrm{N}$ concentrations. 


\subsection{Explaining Spatial Distribution of Leaf $N$}

One of the best performing empirical models based on SR_RE3 was used to create leaf N maps over time (Figure 5). Figure 5 shows the realistic patterns of leaf $\mathrm{N}$ concentrations in the southern part, KNP and the spatial distribution and variation of leaf $\mathrm{N}$ is influenced by a number of variables, including seasons. The variability of leaf $\mathrm{N}$ is clear during peak productivity (see Figure 5, May 2016) and less during dry season (Figure 5, July and August map). In addition, mean annual precipitation, altitude (digital elevation model), slope, aspect, fire frequency and geology were analysed. The correlation results showed that mean annual precipitation and altitude significantly influence $(p<0.05)$ the spatial distribution of leaf $\mathrm{N}$ concentrations (Figure 6). There is a pronounced regional effect of the west - east gradient of precipitation with the western part receiving higher precipitation. The process of nutrient uptake and dissolving of organic matter is facilitated by the availability of water or by precipitation [29]. Altitude is one of the topographic features that introduce heterogeneity, patchiness of nutrients distribution and variation in the Lowveld. Bottomlands and valley areas have high nutrient concentration potential as compared to crest or mid-slopes, independent of the geological type. High nutrients in the bottomlands are due to the run-off from the high slopes.

Using the analysis of variance (ANOVA), results indicated that geology and fire frequency significantly influence the spatial distribution of leaf $\mathrm{N}$ distribution and variation over time. Areas characterized by high fire returns or frequency have significantly higher leaf $\mathrm{N}$ concentrations (See Figure 7, Table 4). Fire is known to enhance forage availability in the savanna ecosystem by suppressing tree and unpalatable grass growth and creates favourable conditions for highly nutritious and palatable grass species to grow $[32,49,50]$. On the other hand, geology as indicated above, influences the quality of the grass in the Lowveld. The granite type of soil has generally lower nutrient concentrations as compared to gabbro and basalt, including lava and shale. In this study, though leaf $\mathrm{N}$ significantly varies across geological types, granite still has relatively higher leaf $\mathrm{N}$ concentration (Figure 7, Table 4). This could be due to the complexities and heterogeneities imposed by the topographic features such as bottomlands and sodic sites within the granite, with relatively higher leaf $\mathrm{N}$ concentrations [31,51]. Again, the influence of environmental factors on the leaf $\mathrm{N}$ concentration is scale dependent. Locally, disturbances such as fire, grazing impact and mega herbivores could have a major influence on leaf nutrient concentrations, while at the regional scale, the influence of climate factors i.e., precipitation and geology could be important [49].

Table 4. Influence of geological types and fire frequency on leaf $\mathrm{N}$ spatial distribution.

\begin{tabular}{ccc}
\hline & F-Statistics & Significance Level $(\boldsymbol{p}<\mathbf{0 . 0 5})$ \\
\hline Geo vs. STDEV N $(\%)$ & $\mathrm{F}(10,610)=5.4770$ & yes \\
Geo vs. Mean N $(\%)$ & $\mathrm{F}(10,610)=3.8157$ & yes \\
Geo vs. Median N $(\%)$ & $\mathrm{F}(10,610)=2.0364$ & yes \\
Fire Freq vs. STDEV N $(\%)$ & $\mathrm{F}(9611)=5.0712$ & yes \\
Fire Freq vs. Mean N $(\%)$ & $\mathrm{F}(9611)=6.1198$ & yes \\
Fire Freq vs. Median N $(\%)$ & $\mathrm{F}(9611)=4.8006$ & yes \\
\hline
\end{tabular}

Geo = geological types; Freq = frequency. 

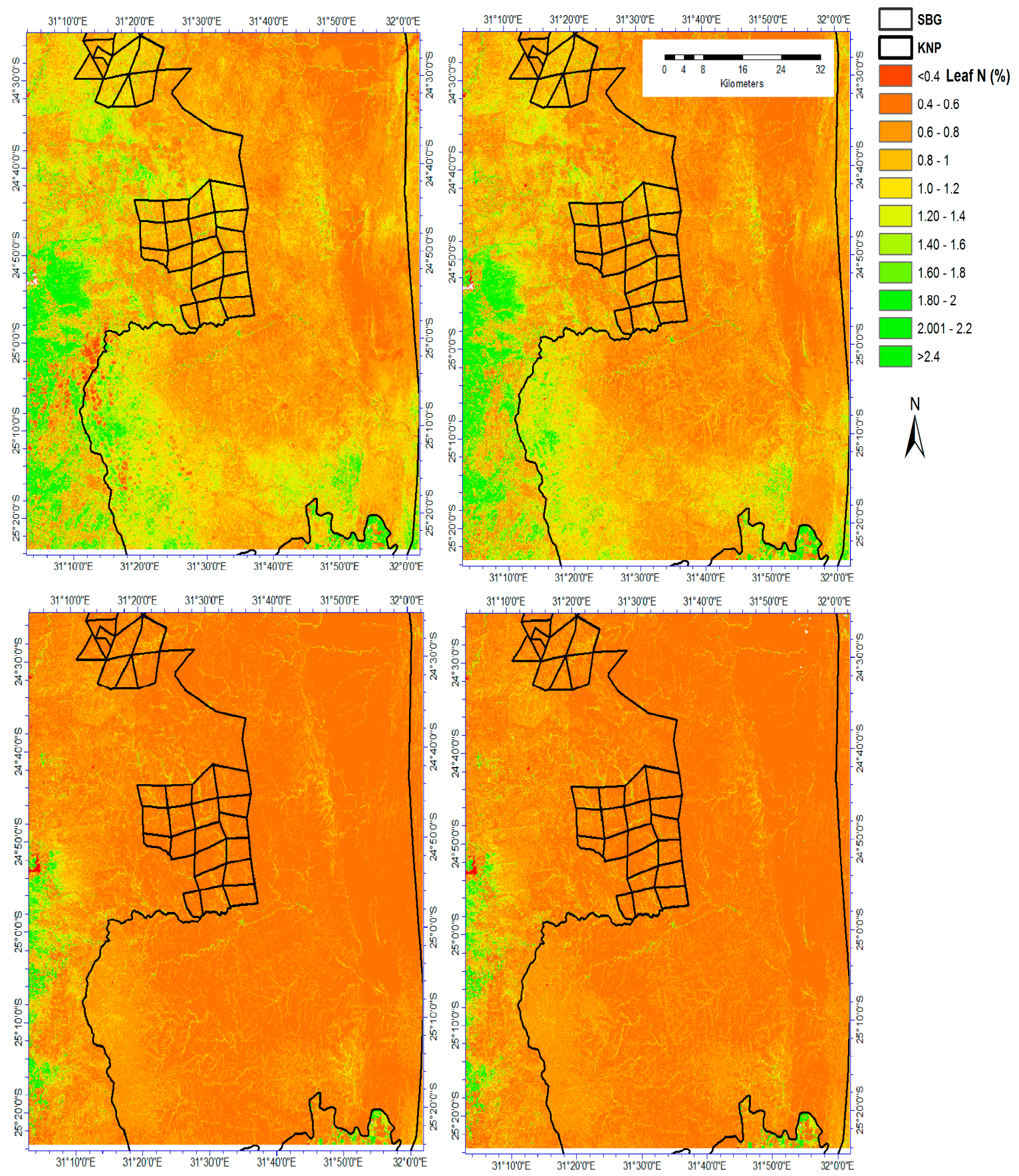

Figure 5. Spatial distribution of leaf nitrogen concentrations (\%) derived from field spectrometer based models applied on Sentinel-2 image. Top: end of wet season (4 and 23 May 2016), and bottom: dry season (23 July and 12 August 2016). 


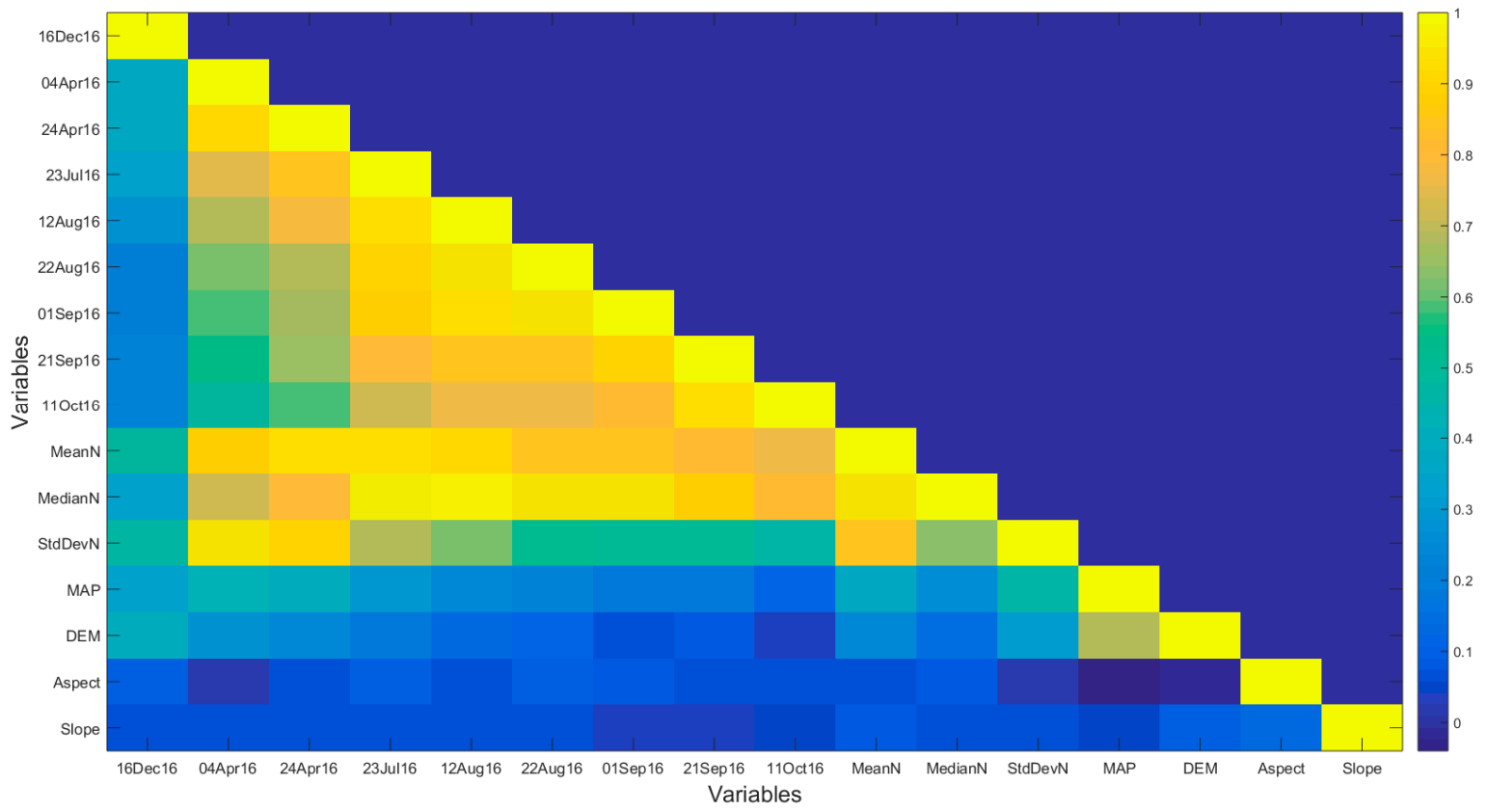

Figure 6. Cross-correlations between leaf nitrogen concentration for various dates with various environmental variables (MAP = mean annual precipitation, $\mathrm{DEM}=$ digital elevation model, $\mathrm{N}=$ leaf nitrogen concentrations $(\%))$.
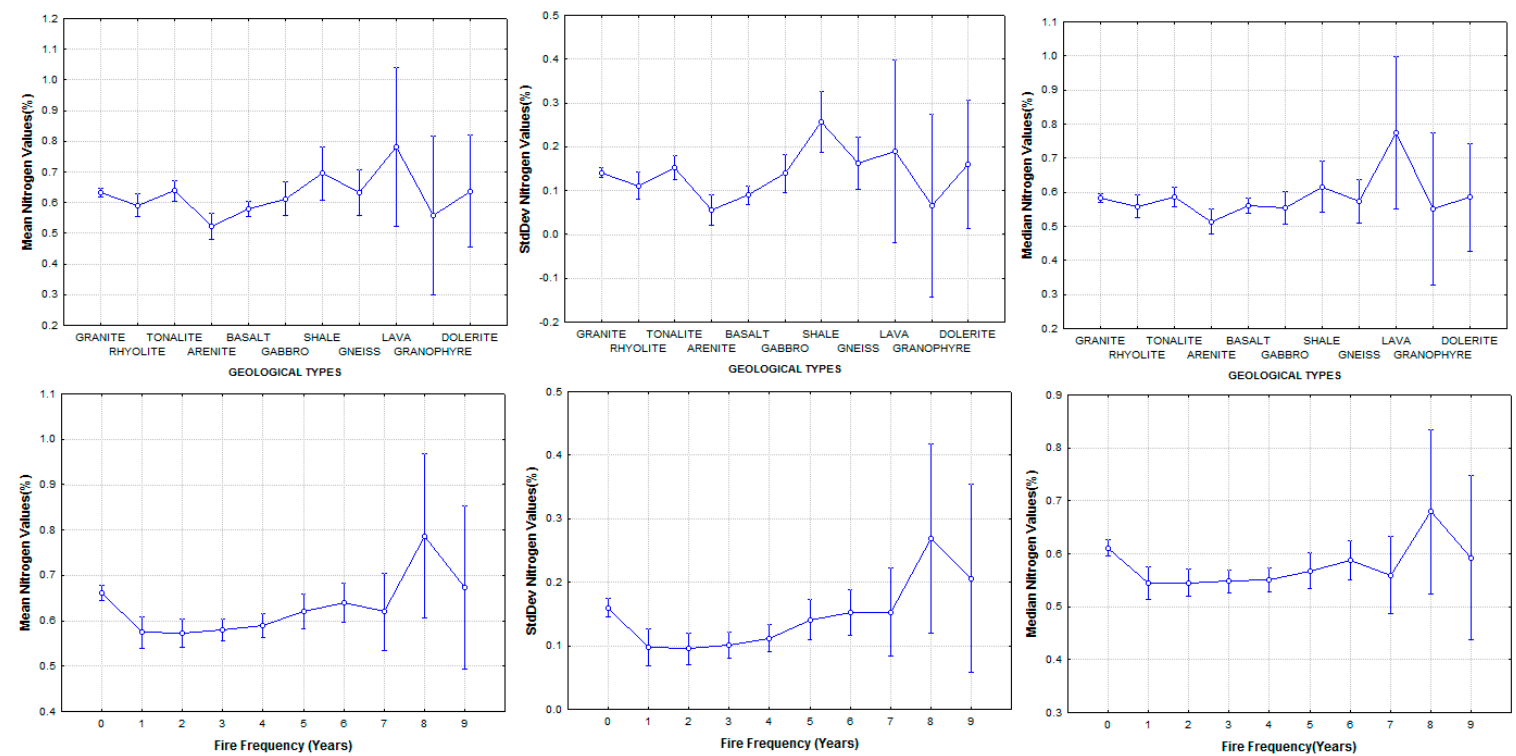

Figure 7. The analysis of the influence of geological types (top) and fire frequency (below) on the variation of leaf $\mathrm{N}$ data, mean, median and standard deviation, derived from nine months or granules of spatial data.

\section{Conclusions}

New and freely available Sentinel-2 data has the potential to estimate leaf $\mathrm{N}$ as an indicator of rangeland quality with the inclusion of red edge bands. The red edge based indices (especially simple ratio based on 705 and $783 \mathrm{~nm}$ ), CI and MTCI based on simulated Sentinel-2 data showed higher potential to estimate leaf $\mathrm{N}$. The latter has been achieved because the red edge position is known to relate to leaf $\mathrm{N}$ and chlorophyll. Even though spectral bands did not yield higher estimation accuracy, most of them were significantly related to leaf N. ASD reflectance data could be useful in the estimation 
of leaf N, provided there is a good red edge embedded satellite data such as Sentinel-2. Geology and fire frequency significantly influence the spatial distribution of leaf $\mathrm{N}$. Topographic features such as altitude significantly influenced the spatial distribution of leaf $\mathrm{N}$, while aspect and slope did not. Monitoring the spatial distribution of nutrients is crucial for understanding the feeding patterns and movements of the herbivores, and is useful to the improvement of rangeland management and planning tools such as stocking rates and rangeland carrying capacity.

Acknowledgments: We would like to thank CSIR, National Research Foundation (NRF)—SASSCAL Project and European Union's Horizon 2020 research and innovation programme under grant agreement No. 641762 (ECOPOTENTIAL Project) for providing funds to undertake this work. I would like to thank SANPARKS scientific services at Skukuza for facilitating field work activities and providing other ancillary datasets. I would also like to thank CSIR's Meraka Institute, Terradue and South African National Space Agency for downloading and processing Sentinel-2 data. I am grateful to Cecilia Masemola and Lucas Mashele (Bushbuckridge area) for field work assistance. I would further like to thank the Editor and anonymous reviewers for their constructive comments, which eventually improved the quality of this manuscript.

Author Contributions: Abel Ramoelo (A.R.) conceptualized the idea, collected, analyzed the data and wrote the manuscript. Moses A. Cho (M.A.C.) contributed on the conceptualization of the idea and paper writing.

Conflicts of Interest: The authors declare no conflict of interest.

\section{References}

1. Child, R.D.; Frasier, G.W. ARS range research. Rangelands 1992, 14, 17-32.

2. Friedl, M. Range condition assessment and the concept of thresholds: A viewpoint. J. Range Manag. 1991, 44, 422-426. [CrossRef]

3. United Nations, Department of Economic and Social Affairs, Population Division-UNPD. World Population Prospects: The 2015 Revision, Methodology of the United Nations Population Estimates and Projections; ESA/P/WP.242; United Nations: New York, NY, USA, 2015.

4. Thornton, P.K. Livestock production: Recent trends, future prospects. Philos. Trans. R. Soc. 2010, 365, 2853-2867. [CrossRef] [PubMed]

5. FAO (Food and Agriculture Organization of the United Nations). Land Degradation Assessment in Drylands (LADA). 2010. Available online: http:/ / www.fao.org/nr/lada/ (accessed on 15 September 2017).

6. Palmer, A.R.; Bennett, J.E. Degradation of communal rangelands in South Africa: Towards an improved understanding to inform policy. Afr. J. Range Forage Sci. 2013, 30, 57-63. [CrossRef]

7. Grant, C.C.; Peel, M.; Zambatis, N.; van Ryssen, J.B.J. Nitrogen and phosphorus concentration in faeces: An indicator of range quality as a practical adjunct to existing range evaluation methods. Afr. J. Range Forage Sci. 2000, 17, 81-92. [CrossRef]

8. Ben-Shahar, R.; Coe, M.J. The relationships between soil factors, grass nutrients and the foraging behaviour of wildebeest and zebra. Oecologia 1992, 90, 422-428. [CrossRef] [PubMed]

9. Kaszta, Z.; Marino, J.; Ramoelo, A.; Wolff, E. Bulk feeder or selective grazer: African buffalo space use patterns based on fine-scaled remotely sensed data on forage quality and quantity. Ecol. Model. 2016, 323, 115-122. [CrossRef]

10. Ramoelo, A.; Skidmore, A.K.; Cho, M.A.; Mathieu, R.; Heitkönig, I.M.A.; Dudeni-Tlhone, N.; Schlerf, M.; Prins, H.H.T. Non-linear partial least square regression increases the estimation accuracy of grass nitrogen and phosphorus using in situ hyperspectral and environmental data. ISPRS J. Photogramm. Remote Sens. 2013, 82, 27-40. [CrossRef]

11. Mutanga, O.; Skidmore, A.K. Integrating imaging spectroscopy and neural networks to map grass quality in the Kruger National park, South Africa. Remote Sens. Environ. 2004, 90, 104-115. [CrossRef]

12. Skidmore, A.K.; Ferwerda, J.G.; Mutanga, O.; van Wieren, S.E.; Peel, M.; Grant, R.C.; Prins, H.H.T.; Balcik, F.B.; Venus, V. Forage quality of savannas-Simultaneously mapping foliar protein and polyphenols for trees and grass using hyperspectral imagery. Remote Sens. Environ. 2010, 114, 64-72. [CrossRef]

13. Knox, N.M.; Skidmore, A.K.; Prins, H.H.T.; Heitkönig, I.M.A.; Slotow, R.; van der Waal, C.; de Boer, W.F. Remote sensing of forage nutrients: Combining ecological and spectral absorption feature data. ISPRS J. Photogramm. Remote Sens. 2012, 72, 27-35. [CrossRef] 
14. Cho, M.A.; Skidmore, A.K. A new technique for extracting the red edge position from hyperspectral data: The linear extrapolation method. Remote Sens. Environ. 2006, 101, 181-193. [CrossRef]

15. Curran, P.J.; Dungan, J.L.; Macler, B.A.; Plummer, S.E. The effect of a red leaf pigment on the relationship between red edge and chlorophyll concentration. Remote Sens. Environ. 1991, 35, 69-76. [CrossRef]

16. Ramoelo, A.; Skidmore, A.K.; Cho, M.A.; Schlerf, M.; Mathieu, R.; Heitkönig, I.M.A. Regional estimation of savanna grass nitrogen using the red-edge band of the spaceborne RapidEye sensor. Int. J. Appl. Earth Obs. Geoinf. 2012, 19, 151-162. [CrossRef]

17. Ramoelo, A.; Cho, M.A.; Mathieu, R.; Madonsela, S.; van de Kerchove, R.; Kaszta, Z.; Wolff, E. Monitoring grass nutrients and biomass as indicators of rangeland quality and quantity using random forest modelling and WorldView-2 data. Int. J. Appl. Earth Obs. Geoinf. 2015, 43, 43-54. [CrossRef]

18. Ramoelo, A.; Cho, M.A.; Mathieu, R.; Skidmore, A. The potential of Sentinel-2 spectral configuration to assess rangeland quality. J. Appl. Remote Sens. 2015, 9, 094096. [CrossRef]

19. Mutanga, O.; Skidmore, A.K. Red edge shift and biochemical content in grass canopies. ISPRS J. Photogramm. Remote Sens. 2007, 62, 34-42. [CrossRef]

20. Huang, Z.; Turner, B.J.; Dury, S.J.; Wallis, I.R.; Foley, W.J. Estimating foliage nitrogen concentration from HYMAP data using continuum removal analysis. Remote Sens. Environ. 2004, 93, 18-29. [CrossRef]

21. Kokaly, R.F.; Asner, G.P.; Ollinger, S.V.; Martin, M.E.; Wessman, C.A. Characterizing canopy biochemistry from imaging spectroscopy and its application to ecosystem studies. Remote Sens. Environ. 2009, 113 (Suppl. 1), S78-S91. [CrossRef]

22. Muharam, F.M.; Maas, S.J.; Bronson, K.F.; Delahunty, T. Estimating cotton nitrogen nutrition status using leaf greenness and ground cover information. Remote Sens. 2015, 7, 7007-7028. [CrossRef]

23. Caturegli, L.; Casucci, M.; Lulli, F.; Grossi, N.; Gaetani, M.; Magni, S.; Bonari, E.; Volterrani, M. GeoEye-1 satellite versus ground-based multispectral data for estimating nitrogen status of turfgrasses. Int. J. Remote Sens. 2015, 36, 2238-2251. [CrossRef]

24. Wang, Z.; Skidmore, A.K.; Darvishzadeh, R.; Heiden, U.; Heurich, M.; Wang, T. Leaf nitrogen content indirectly estimated by leaf traits derived from the PROSPECT model. IEEE J. Sel. Top. Appl. Earth Obs. Remote Sens. 2015, 8, 3172-3182. [CrossRef]

25. Wang, Z.; Wang, T.; Darvishzadeh, R.; Skidmore, A.K.; Jones, S.; Suarez, L.; Woodgate, W.; Heiden, U.; Heurich, M.; Hearne, J. Vegetation indices for mapping canopy foliar nitrogen in a mixed temperate forest. Remote Sens. 2016, 8, 491. [CrossRef]

26. Yoder, B.J.; Pettigrew-Crosby, R.E. Predicting nitrogen and chlorophyll content and concentrations from reflectance spectra $(400-2500 \mathrm{~nm})$ at leaf and canopy scales. Remote Sens. Environ. 1995, 53, 199-211. [CrossRef]

27. Cho, M.; Skidmore, A.K.; Corsi, F.; van Wieren, S.; Sobhan, I. Estimation of green grass/herb biomass from airborne hyperspectral imagery using spectral indices and partial least square regressions. Int. J. Appl. Earth Obs. Geoinf. 2007, 9, 414-424. [CrossRef]

28. Venter, F.J.; Scholes, R.J.; Eckhardt, H.C. Abiotic template and its associated vegetation pattern. In The Kruger Experience: Ecology and Management of Savanna Heterogeneity; Toit, J.T.D., Kevin, H.R., Biggs, H.C., Eds.; The Island Press: London, UK, 2003; pp. 83-129.

29. Pickectt, S.T.A.; Gadenasso, M.L.; Benning, T.L. (Eds.) Biotic and Abiotic Variability as Key Determinants of Savanna Heterogeneity at Spatiotemporal Scales; Island Press: London, UK, 2003.

30. Sankaran, M. Fire, grazing and the dynamics of tall-grass savannas in the Kalakad-Mundanthurai Tiger Reserve, South India. Conserv. Soc. 2005, 3, 4-25.

31. Grant, C.C.; Scholes, M.C. The importance of nutrient hot-spots in the conservation and management of large wild mammalian herbivores in semi-arid savannas. Biol. Conserv. 2006, 130, 426-437. [CrossRef]

32. Mucina, L.; Rutherford, M.C. The Vegetation of South Africa, Lesotho and Swaziland; SANBI: Cape Town, South Africa, 2006.

33. Jordan, C.F. Derivation of leaf area index from quality of light on the forest floor. Ecology 1969, 50, 663-666. [CrossRef]

34. Barnes, E.M.; Clarke, T.R.; Richards, S.E.; Colaizzi, P.D.; Haberland, J.; Kostrzewski, M.; Waller, P.; Choi, C.; Riley, E.; Thompson, T.; et al. Coincident detection of crop water stress, nitrogen status and canopy density using ground-based multispectral data. In Proceedings of the Fifth International Conference on Precision Agriculture, Bloomington, MN, USA, 16-19 July 2000. 
35. Clevers, J.G.P.W.; Gitelson, A.A. Remote estimation of crop and grass chlorophyll and nitrogen content using red-edge bands on Sentinel-2 and 3. Int. J. Appl. Earth Obs. Geoinf. 2013, 23, 344-351. [CrossRef]

36. Gitelson, A.; Merzlyak, M.N. Spectral reflectance changes associated with autumn senescence of Aesculus hippocastanum L. and Acer platanoides L. leaves. Spectral features and relation to chlorophyll estimation. J. Plant Physiol. 1994, 143, 286-292. [CrossRef]

37. Sims, D.A.; Gamon, J.A. Relationships between leaf pigment content and spectral reflectance across a wide range of species, leaf structures and developmental stages. Remote Sens. Environ. 2002, 81, 337-354. [CrossRef]

38. Gitelson, A.A.; Gritz, Y.; Merzlyak, M.N. Relationships between leaf chlorophyll content and spectral reflectance and algorithms for non-destructive chlorophyll assessment in higher plant leaves. J. Plant Physiol. 2003, 160, 271-282. [CrossRef] [PubMed]

39. Gitelson, A.A.; Keydan, G.P.; Merzlyak, M.N. Three-band model for noninvasive estimation of chlorophyll, carotenoids, and anthocyanin contents in higher plant leaves. Geophys. Res. Lett. 2006, 33, L11402. [CrossRef]

40. Dash, J.; Curran, P.J. The MERIS terrestrial chlorophyll index. Int. J. Remote Sens. 2004, 25, 5403-5413. [CrossRef]

41. Guyot, G.; Baret, F. Utilisation de la haute résolution spectrale pour suivre l'état des couverts végétaux. In Proceedings of the 4th International Colloquium on Spectral Signatures of Objects in Remote Sensing. ESA SP-287, Assois, France, 18-22 January 1988; pp. 279-286.

42. Bunke, O.; Droge, B. Bootstrap and cross-validation estimates of the prediction error for linear regression models. Ann. Stat. 1984, 12, 1400-1424. [CrossRef]

43. Efron, B. Estimating the error rate of a prediction rule: Improvement on cross-validation. J. Am. Stat. Assoc. 1983, 78, 316-331. [CrossRef]

44. Efron, B.; Tibshirani, R. Improvements on cross-validation: The 632+ Bootstrap Method. J. Am. Stat. Assoc. 1997, 92, 548-560.

45. Ullah, S.; Si, Y.; Schlerf, M.; Skidmore, A.K.; Shafique, M.; Iqbal, I.A. Estimation of grassland biomass and nitrogen using MERIS data. Int. J. Appl. Earth Obs. Geoinf. 2012, 19, 196-204. [CrossRef]

46. Cho, M.A.; Ramoelo, A.; Debba, P.; Mutanga, O.; Mathieu, R.; van Deventer, H.; Ndlovu, N. Assessing the effects of subtropical forest fragmentation on leaf nitrogen distribution using remote sensing data. Landsc. Ecol. 2013, 28, 1479-1491. [CrossRef]

47. Loozen, Y.; Rebel, K.T.; Karssenberg, D.; Wassen, M.J.; Sardans, J.; Penuelas, J.; de Jong, S.M. Regional detection of canopy nitrogen in Mediterranean forests using the spaceborne MERIS Terrestrial Chlorophyll Index. J. Biogeosci. Discuss. 2017, 1-32. [CrossRef]

48. Zengeya, F.M.; Mutanga, O.; Murwira, A. Linking remotely sensed forage quality estimates from WorldView-2 multispectral data with cattle distribution in a savanna landscape. Int. J. Appl. Earth Obs. Geoinf. 2013, 21, 513-524. [CrossRef]

49. Sankaran, M.; Hanan, N.P.; Scholes, R.J.; Ratnam, J.; Augustine, A.J.; Cade, B.S.; Gignoux, J.; Higgins, S.I.; Le Roux, X.; Ludwig, F.; et al. Determinants of woody cover in African. Nature 2005, 438, 846-849. [CrossRef] [PubMed]

50. Van Wilgen, B.W. The evolution of fire management practices in savanna protected areas in South Africa. S. Afr. J. Sci. 2009, 105, 343-349. [CrossRef]

51. Scholes, R.J. The influence of soil fertility on the ecology of Southern African dry savannas. J. Biogeogr. 1990, 17, 415-419. [CrossRef]

(C) 2018 by the authors. Licensee MDPI, Basel, Switzerland. This article is an open access article distributed under the terms and conditions of the Creative Commons Attribution (CC BY) license (http://creativecommons.org/licenses/by/4.0/). 